\title{
Imagens e sonoridades da formação: concepções de arte e seu ensino na perspectiva de licenciandos em Artes
}

\author{
MARIA CRISTINA DA ROSA FONSECA DA SILVA \\ REGINA FINCK SCHAMBECK
}

\section{Resumo}

$\mathrm{O}$ artigo tem por objetivo revelar as concepções de arte e seu ensino na perspectiva de licenciandos em Artes Visuais e Música. Esses alunos selecionaram imagens e sonoridades a partir da pergunta: "Como se constrói um professor de Artes?" O referencial teórico sócio-histórico foi utilizado para auxiliar nas análises de depoimentos, relatórios de estágio e nas postagens escritas no ambiente virtual. Esse material

Palavras-chave: Formação docente, Artes Visuais, Música reflete um processo de amadurecimento dos licenciandos na construção do desejo pela docência e a compreensão do universo educacional que permeia a escola contemporânea. 


\title{
Images and training sounds: conceptions of art and its teaching undergraduates in the perspective of Arts
}

\author{
MARIA CRISTINA DA ROSA FONSECA DA SILVA \\ REGINA FINCK SCHAMBECK
}

\begin{abstract}
This article aims to reveal the conceptions of art and its education by the perspective of the undergraduates of Visual Arts and Music. These students selected images and sounds from the question "How is an art teacher constructed?" The socio- cultural theoretical framework was used to help in the analysis of testimonials, internship reports and posts written in virtual environment. This material reflects a process of growing of the undergraduates in the teaching desire and in the understanding of the educational universe that permeates the contemporary school.
\end{abstract}

Keywords:

Teacher training, Visual Arts, Music 


\title{
Imágenes y sonoridades de la formación: concepciones de arte y su enseñanza en la perspectiva de licenciandos en Artes
}

\author{
MARIA CRISTINA DA ROSA FONSECA DA SILVA \\ REGINA FINCK SCHAMBECK
}

\section{Resumen}

El artículo tiene como objetivo revelar las concepciones de arte y su enseñanza en la perspectiva de licenciandos en Artes Visuales y Música. Eses alumnos seleccionaron imágenes y sonoridades a partir de la pregunta: “¿Cómo se construye un profesor de Artes?" El referencial teórico socio-histórico fue utilizado para auxiliar en los análisis de declaraciones, informes de prácticas y en las publicaciones escritas en el ambiente virtual. Ese material

Palabras clave: Formación docente, Artes Visuales, Música refleja un proceso de maduración de los licenciandos en la construcción del deseo por la docencia y la comprensión del universo educacional que permea la escuela contemporánea. 


\section{Apresentação}

Faz mais de dez anos que atuamos juntas na formação de professores nas licenciaturas em Artes Visuais e Música. Nessa caminhada, a partir da articulação entre ensino, pesquisa e extensão, muitas questões surgiram, foram problematizadas e, gradativamente, buscamos construir alternativas viáveis dentro da realidade. Igualmente construímos nossa formação docente, pois, ao tecer a formação de nossos alunos de licenciatura, fortalecemos as vivências, ampliamos os repertórios das práticas de ensinar, ao mesmo tempo em que amadurecemos nossas próprias perspectivas em relação à importância de uma visão mais humanizada que a arte proporciona. Esse repertório foi sendo elaborado no transcorrer das orientações de estágio, sob a influência de diferentes momentos na área, novas visualidades e muitas sonoridades, desde a implantação da Educação Artística, até a mudança para o Ensino de Arte, já que somos a geração 80 da Arte/ Educação1.

Trata-se, o presente artigo, da análise do processo reflexivo de duas professoras de licenciaturas, uma na área de Artes Visuais e outra na área de Música, com seus estudantes, a partir da investigação sobre o processo de tornar-se docente em Artes.

No primeiro caso, temos um grupo formado por 15 estudantes da disciplina de Estágio I, que consistiu na preparação e atuação dos estudantes da quarta fase da licenciatura em Artes Visuais para o Ensino das Artes na Educação Infantil. Os estudantes tiveram como processo anterior, na terceira fase, a disciplina de Prática de Ensino I, com o objetivo de "Analisar criticamente os aspectos do planejamento e desenvolvimento do ensino de arte na educação escolar infantil e primeiras séries do ensino fundamental ${ }^{2}$. Nessa oportunidade, os estudantes puderam observar o campo de estágio e propor seu projeto de atuação para o semestre 
seguinte. Os alunos participantes da disciplina atuaram em três campos distintos: o Colégio de Aplicação da Universidade Federal de Santa Catarina - UFSC, situado no bairro Trindade; a Escola Municipal José do Valle Pereira da rede municipal de Florianópolis, no bairro João Paulo; e a Escola Estadual Lauro Müller, no Centro da cidade. A maioria dos alunos desenvolveu as ações de estágio em duplas, somente dois alunos atuaram sozinhos. Por meio da disciplina Estágio I, os estudantes puderam conhecer as visualidades existentes nas escolas. Uma grande parte delas estereotipadas, essa lacuna possibilitou espaços para que os projetos de ensino pudessem acolher as contribuições das crianças e da inserção dessas no campo da arte contemporânea.

Na licenciatura em Música temos um grupo formado por 27 estudantes da segunda fase do curso, da disciplina de Música e Escola II. A atividade consistiu na inserção do aluno no contexto de espaços educativos. Nesta disciplina também se previa a compreensão crítica da escola como produto da cultura e, ao mesmo tempo, a percepção de suas características de produtora e reprodutora das condições sociais. Os alunos também observaram como os conteúdos de Música estão sendo inseridos na escola a partir da publicação da Lei 11.769 (BRASIL, 2008) e as funções sociais desempenhadas pela música neste contexto.

Nesta disciplina, os estudantes tiveram como objetivo "compreender a escola enquanto instituição que compõe a atual estrutura sociocultural e política, construindo princípios norteadores para uma educação musical capaz de intervir nas condições contextuais da escola ${ }^{3}$. Assim, os estudantes puderam contextualizar espaços educativos possíveis para a atuação do educador musical; refletir sobre a situação atual do ensino de Música no Brasil, a partir de observações do espaço escolar; e, da mesma forma, refletir sobre a relação entre música no currículo escolar e música na vida de crianças e adolescentes.

Devido ao grande número de acadêmicos para as atividades de observação, e procurando interferir o mínimo possível nas atividades das turmas observadas, os participantes da disciplina foram divididos para atuar em sete escolas da rede Municipal de Educação de Florianópolis, doravante nominadas de E.B.M. (Escola Básica Municipal). As unidades selecionadas oferecem a disciplina de Música aos alunos da educação fundamental. Foram determinadas como campo de observação as unidades de ensino, a seguir: E.B.M. João Gonçalves Pinheiro, localizada no bairro Rio Tavares; E.B.M. Virgílio Várzea, em Canasvieiras; E.B.M. Luiz Candido da Luz, no bairro Vargem do Bom Jesus; E.B.M. Vitor Miguel, no bairro Itacorubi, E.B.M. Acácio Garibaldi São Thiago, na Bar- 
ra da Lagoa; E.B.M. Padre João Alfredo Rohr, no bairro Córrego Grande; e, finalmente, a E.B.M. Domícia Maria da Costa, localizada no bairro Saco Grande. Grande parte dos alunos distribuiu as observações de acordo com a matriz curricular em que a disciplina de Música era oferecida na unidade escolar, de modo a evitar que mais de dois alunos fizessem as observações no mesmo horário.

Abordamos os relatos de estágio de observação como registros que auxiliam a reflexão sobre a atuação na escola, relatos de vivências entremeadas de dúvidas, fazeres, experiências sociais, conquistas e aprendizagens. Igualmente, visualizar os relatórios como documentos de registros, que permitem incorporar mudanças que caminham, como aponta Saviani (200o), "do senso comum à consciência filosófica” e, acima de tudo, de reflexões sobre o tornar-se professor na escola contemporânea, da compreensão do campo das artes e suas diferentes teorias e da contribuição singular desse campo para a humanização da sociedade.

\section{Elementos que fundamentam a ação docente em Artes}

Para fins didáticos criamos uma figura que representa os elementos fundantes da carreira de professor de Artes, partindo de um problema central que é como se forma o professor de Artes? Sugerimos alguns pontos de reflexão como temas abordados de forma contundente nas disciplinas dos cursos de Artes. No primeiro plano definimos cinco categorias: contextual, simbólica, pedagógica, artística e trabalho.

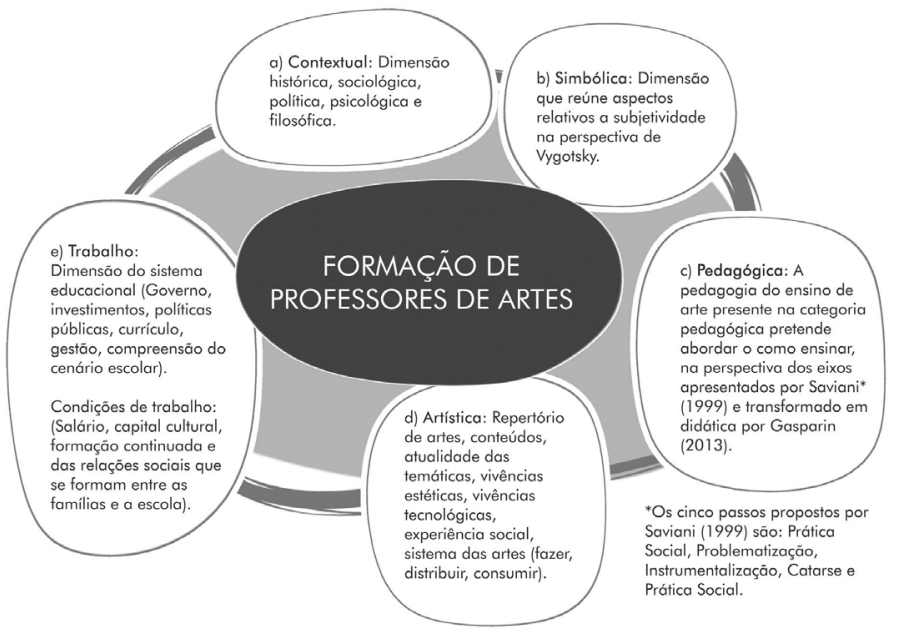


Cada uma das categorias desdobra-se em diferentes dimensões. Na categoria contextual, organizamos cinco dimensões, a saber: política, histórica, sociológica, filosófica e psicológica. Essa primeira categoria daria conta dos conhecimentos fundantes necessários para compreender o contexto em que vivemos, onde a escola está inserida e o papel das artes nesse cenário, inclusive como apoio para a compreensão das mentalidades nos diferentes contextos artísticos.

Na categoria simbólica, situam-se os aspectos referentes à subjetividade, ao desejo, à humanidade presente no ato de educar como partilha de conhecimento e de apropriar-se da Arte socialmente. Fundamentamo-nos na concepção de subjetividade proposta por Vigotsky (2004), a qual não precede de uma consciência coletiva, acontece em concomitância, pois a subjetividade não se desvincula da realidade social, como abordado por Peres (2002).

Ao mesmo tempo em que separamos as categorias, como já enunciado, apenas para fins didáticos, é necessário reafirmar a articulação cotidiana delas e de suas diferentes dimensões. A pedagogia do ensino de Arte, presente na categoria pedagógica, pretende abordar o como ensinar, na perspectiva dos eixos apresentados por Saviani (2009) e transformados em prática-pedagógica por Gasparin (2002) 4 .

A acadêmica Valentina ${ }^{5}$, em seu depoimento analisando a prática pedagógica de Artes Visuais como abordagem criadora, apontou que:

No fim das contas, professor de Artes é uma mala! Mala cheia de bugigangas, cheia de possibilidades, cheia de histórias experienciadas. Mala cheia de sonhos, utopias, coisas coloridas, coisas velhas, bossas novas. Mas é preciso, num dia desses, assim... desses que pedem ordem de recolhida, desses de férias do meio do ano, desses de céus cinzas, nuvens pela cabeça... é preciso abrir a mala pra tirar o excesso. Dias ruins sempre são bons. É tempo de reparo das peças. Dias ou noites de críticas autoconstrutivistas, como um chá, valem a pena. (Depoimento, Valentina).

O que fazer com todos os elementos dentro da mala? Como organizar esse processo de modo que aconteça uma aprendizagem significativa? Como elencar temas atuais que permitam selecionar novas visualidades e, ao mesmo tempo, democratizar o acesso aos conhecimentos historicamente produzidos pela humanidade? Desenhar uma pedagogia his- 
tórico-crítica para o ensino de Arte nas licenciaturas amplia as condições de trabalho do professor para acolher o aluno com ser pensante, como ser de múltiplas perspectivas, tanto na escola como em outros espaços sociais. Cabe ressaltar o acolhimento às diferentes características dos estudantes, seus contextos econômicos, étnicos, de gênero, de opção sexual, de acessibilidade física ou sensorial.

Na categoria artística, incluímos a Arte e seus processos desde a criação até a distribuição, a organização e seleção dos conteúdos formativos (quem define o que o professor aprende sobre Arte?), aspectos estéticos relativos à fruição, à configuração do sistema artístico e da experiência social de fazer arte em diferentes condições. Nessa dimensão, salientamos as vivências estéticas na vida do professor e de seus alunos, bem como a fruição de objetos artísticos, da reflexão sobre o papel da indústria cultural na formação de consumidores midiáticos, das tecnologias e sua inserção no cotidiano. Não podemos desconsiderar a ambiguidade das imagens presentes no contexto contemporâneo, como aborda Ramirez (2004).

Finalmente, o papel social das Artes na formação humana, conforme menciona Nogueira (2013), ocorre a partir da experiência que parece subjetiva e singular e, ao mesmo tempo, é parte de um sentimento cultural mais amplo, isto é, produzido sócio-historicamente dentro das condições sociais existentes.

Na quinta categoria nominada de trabalho, inserimos a dimensão do sistema educacional, os aspectos políticos e econômicos das condições de trabalho e das relações sociais que se formam entre as famílias e a escola. Na dimensão sistema educacional, destacamos a reflexão sobre as políticas públicas e de como elas tecem a formação de professores, definindo perfis e modelos, bem como a participação do Estado como mantenedor da educação pública. Na dimensão condições de trabalho, situam-se talvez os aspectos mais polêmicos da reflexão sobre a atuação dos professores, da valorização salarial e mesmo da hierarquia de organização dos conhecimentos na escola, que pouco privilegiam o professor de Artes e os conteúdos da área, ou mesmo o acesso à produção artística dos docentes como formação de repertório que amplia as condições de sua própria aprendizagem.

Os aspectos curriculares, da participação dos professores de Artes na implementação das políticas públicas, nos processos de gestão e do aprendizado da organização e funcionamento da escola, também se situam na dimensão intitulada sistema educacional. Podemos acrescentar, igualmente, a for- 
mação continuada na perspectiva de um projeto educacional e as relações entre escola e famílias, mudanças de perfil e os limites da atuação docente.

\section{O que dizem os estudantes da licenciatura em Artes Visuais?}

Os estudantes de Artes Visuais apresentam uma escrita bastante poética, metafórica e calcada fortemente na experiência de vida e na prática artística. Nosso escopo de análise primeiro se dá sobre o depoimento dos estudantes no ambiente virtual Moodle. Num grupo de 15 alunos, em que 12 completaram a totalidade da disciplina, nove alunos participaram da seleção de imagens e textos estimulados a partir da questão: Como se constrói a formação de professores de Artes Visuais? Desses, sete são mulheres e dois são homens, composição bastante comum na profissão docente, formada majoritariamente por mulheres. Cada fala estava vinculada a uma imagem. Apresentamos, a seguir, fragmentos de imagens e falas dos participantes.

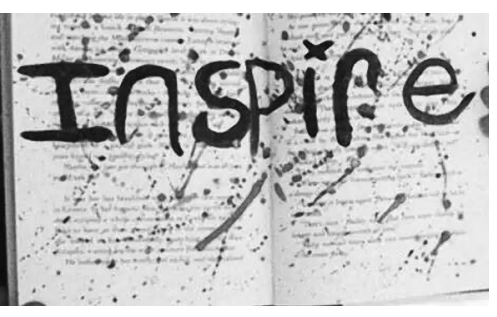

A construção de um professor de Artes pode ser comparada com a construção de uma casa, precisa de um fundamento bom e forte. Isto acontece com muito estudo e pesquisas, (...) e entender os alunos e suas fases. Além disso, tem que haver vontade e disposição para renovar suas aulas e se renovar diariamente.

(...) E, por último, um professor precisa de experiência, através de estágios e bolsas, é onde ele começa a pôr em prática o que aprendeu e está aprendendo. Como em qualquer profissão, o professor precisa da prática e da teoria para se construir como um bom profissional. (Depoimento de Katia)

Para se construir um professor de Artes Visuais, é preciso algo muito peculiar, que não se encontra nas universidades (...), pois de nada adiantaria ter todo conhecimento do mundo se o professor das Artes Visuais não perceber a formiga que sai do nó da madeira, mesmo que toda sua aula pare por causa disso... porque têm momentos que é preciso fazer, mas têm momentos que é preciso parar e só ouvir, sentir, olhar, cheirar, saborear. (Depoimento de Raio de Sol).

Sobre como se constrói um professor de Arte... procuro um alicerce seguro para me estabelecer. Nem meus 50 anos e sendo mãe, definem esta questão, nem Piaget, Vigotsky, Wallon e Ana Mae Barbosa. Ensinar é um ato de dedicação, de responsabili- 
dade... pois levar o lúdico, cores, formas, poesias, em um mundo nada linear, é difícil, vivemos o pictórico dos nossos dias, de manchas e superposições, entre tantos acontecimentos e tecnologias, violências, amores remotos e controles remotos...

Então, buscarmos uma troca com os alunos entre erros e acertos, aprender, relembrar, ensinar, um sorriso, um despertar para algo novo, conhecer cada aluno como um ser singular, usar os sentidos, a emoção para tudo isso... tudo cimentado com racionalidade, estudo e pesquisa... penso que é a grande base para se estabelecer esta construção. (Depoimento de Maria)

Constrói-se por meio de experimentações inter-humanas, fundamentadas na observação e na ação de comunicar-se com alguém. São dias e noites andando em trânsito gigantesco com livros, letras, cores e formas visuais, auditivas, táteis e proprioceptivas. Conhecer eampliar o repertório de obras, acervos, museus e acontecimentos artísticos. Procurar unir o que estuda com sua criação plástica, além do desejo social e aquilo que foge ao coeficiente artístico. Propagar cultura em cada encontro diário. Conceber linguagens, e expandir a expressão. (Depoimento de Sérgio)

Bem comoa desmontagem de uma imagem para que se abstraiam seus fundamentais elementos, um professor que procura apontar suas dificuldades para consigo mesmo ao término de cada aula, de cada semana, de cada particularidade dos momentos, se desmonta para remanejo das partes separadas. Assim também como seus sucessos são uma peça a ser somada no processo todo.

Levar em consideração as vivências, as referências, as experiências, que vão sendo levantadas pelos estudantes é absolutamente importante para a condução do caminho que o tema toma. As pesquisas pessoais teóricas são apoio para suas estratégias de composição de pensamento. Contudo, é vital que a prática artística não esteja separada da vida do professor. (Depoimento de Valentina)

Sinceramente, o processo de construção de um professor leva tempo! O primeiro passo para esta maravilhosa caminhada foi dado pela escolha da profissão, estudo constante, atualização e vivências. A experiência que virá com o tempo, assim como a necessidade de aperfeiçoamento, pois o mundo muda rapidamente, serão inevitáveis. Sentir-se bem para dar aula e viver a cada momento feliz e satisfeito com a escolha de ser professor de Artes Visuais é ter resultados positivos de mudanças no contexto escolar; pois a Arte possibilita mudanças,
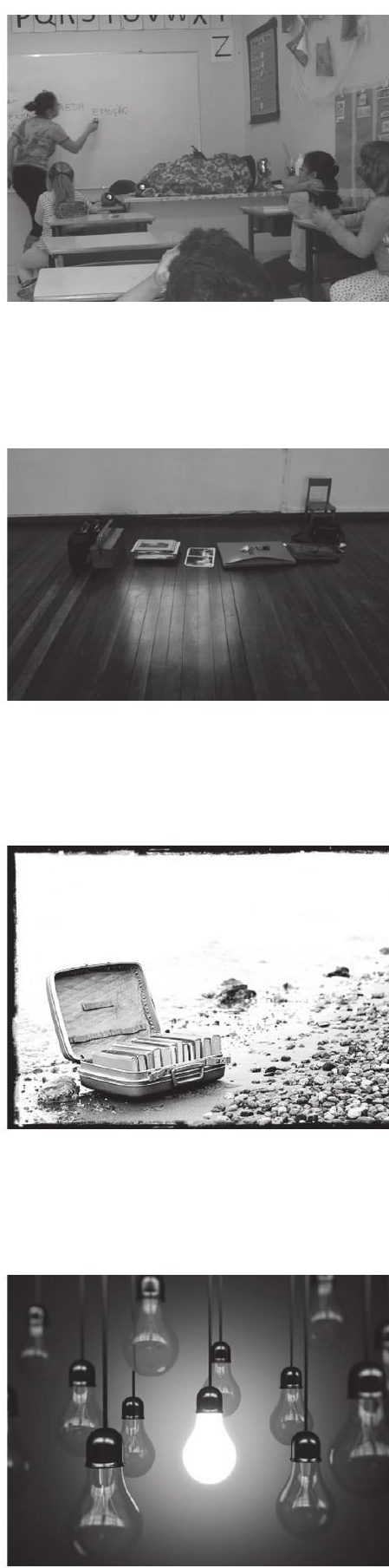


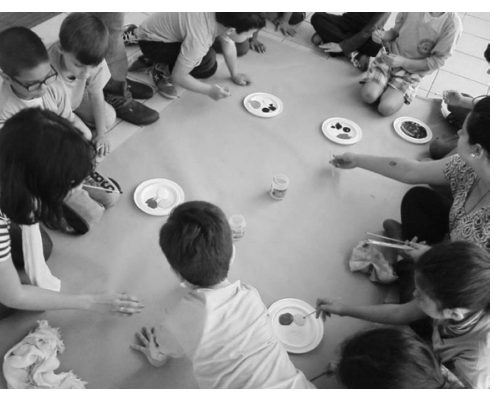

descobertas e abertura para potencialidades de cada ser. É preciso estar atento! (Depoimento de Gabriela)

Se dentro da sociedade capitalista, a educação/conhecimento já é vista como um "bem" quase acessório (sendo assim, a profissão de professor muito desmerecida), a arte, então, ocupa um lugar tão complicado quanto. Para encarar esse desafio, um professor de arte não precisa apenas entender ou simpatizar com a arte ou saber desenhar e pintar lindamente, mas viver a arte, e respirá-la. Tomá-la como uma posição e defendê-la. Acreditar. A formação acadêmica, fundamentação teórica, a didática e o dinamismo são aspectos indispensáveis, acredito, que em qualquer profissão. (Depoimento de Diana)

Um professor de Artes Visuais se constrói a partir de uma vontade. É um processo através do estudo, de um aprimoramento, experienciando com a prática e vivenciando no dia a dia dentro de sala de aula.

O professor de Artes Visuais se constrói a partir do momento em que vê o aluno desenvolvendo suas potencialidades, seus argumentos, suas ideias, seu raciocínio com criatividade e imaginação.

O papel deste professor não é formar um artista, mas sim, fazer com que o aluno atinja seus melhores sentimentos, sua sensibilidade, onde, através da arte, possa discernir o que lhe faz bem e o que lhe faz mal.

Este professor não se constrói sozinho, ele precisa dessa troca, observando cada indivíduo na sua particularidade, criando um fio condutor de confiança, afeto e respeito. (Depoimento de Flavia)

Acredito que um professor de artes se desafia buscando alternativas que conduzam os alunos para o envolvimento nas Artes Visuais, objetivando o ensino desta linguagem. (Depoimento de Laura)

Os depoimentos apontam para diferentes abordagens acerca da formação e posições conceituais que, por vezes, antagonizam-se. Enquanto algumas falas destacam o peso do conhecimento, da formação, do estudo sistematizado, outras falas destacam que "Para se construir um professor de Artes Visuais, é preciso algo muito peculiar, que não se encontra nas universidades (...)" (depoimento de Raio de Sol). Essa peculiaridade podemos interpretar como algo que diz respeito a um conjunto 
de características lúdicas presentes na Educação Infantil. Uma capacidade de brincar, de sentar no chão, de fantasiar, de improvisar e que muitas vezes o ambiente acadêmico não prioriza. De fato, pode-se dizer que há pouco espaço para a formação desse olhar diferenciado para o ensino de Arte na Educação Infantil nas licenciaturas em Artes Visuais. O lugar da formação de professores para a Educação Infantil ocorre, na maioria das vezes, nos cursos de Pedagogia. Por outro lado, a parcela de professores de Artes Visuais que atua na Educação Infantil forma-se, para a compreensão deste contexto, de sua visualidade e ludicidade na própria prática docente ou na formação continuada, muito mais do que nas licenciaturas em Artes Visuais ${ }^{6}$.

Os alunos da Educação Infantil, assim como suas professoras foram, ao longo do processo de estágio supervisionado, parceiros estratégicos para concretizar o aprendizado da prática dos licenciandos. Como apontou uma das estudantes:

\begin{abstract}
Venho descobrindo que dói morder a língua; que a criança que vive em mim está desatualizada, desacostumada, mas que ainda quer brincar; que a risada é sim, o melhor remédio e que viajar é preciso para preencher a mala! Com os próprios pés ou de carona na imaginação. Vontade e criatividade são itens de primeiros-socorros na mala, ferramentas afiadas para grandes edifícios. (Depoimento de Valentina).
\end{abstract}

Por mais que o supervisor de estágio esteja ao lado do estagiário, oriente o planejamento, o desenvolvimento temporal da aula, as escolhas didáticas, os materiais e busque antever o processo da docência, é no contato com as crianças, no modo de falar, ser e conduzir os alunos, que o estagiário sente sua maior dificuldade. Identificar as expectativas das faixas etárias, os desenhos de ser, os modos de olhar para a realidade, as imagens disponíveis na escola, são descobertas que se constrói no dia a dia e com a reflexão que se incorpora nesse processo. A parceria com o professor regente, o cuidado, a disponibilidade, a troca, as vivências conjuntas, configuram contribuições decisivas para o processo educativo do professor em formação.

O inquietante processo de apropriação e execução do planejamento é permeado pela dúvida e, como aponta um dos estagiários: "São dias e noites andando em trânsito gigantesco com livros, letras, cores e formas visuais, auditivas, táteis e proprioceptivas" (depoimento de Sérgio). Buscar coadunar as escolhas artísticas, o planejamento da professora regente, as suas próprias referências, objetivos, metodologias, configurações 
teóricas e todo um arsenal pedagógico disponível para selecionar, fazer escolhas, responsabilizar-se, tornar-se docente: eis aí uma experiência significativa, o primeiro estágio.

As imagens escolhidas pelos estudantes falam de diferentes visualidades, de uma subjetividade coletiva e disponibilizada no processo de construir-se docente, daquilo que deixa marcas, do ser instigado nesses diferentes cenários. Assim, destacamos, a partir de nossa análise e dos registros nos relatórios de estágio, que três delas remetem diretamente para a temática das vivências durante o estágio, mostrando seus alunos, o ambiente da escola, os colegas participantes, enfim, ilustrando o cenário em que foi desencadeada a experiência docente. Mas outro grupo de imagens aborda o tema de forma metafórica: a metáfora da mala, que representa os guardados; a metáfora daquilo que remete ao inventivo, ao que não está posto, a um caminho que precisa ser caminhado; e a metáfora da luz, que remete ao tempo, ao amadurecimento, à descoberta. Ao mesmo tempo em que cada imagem traz as escolhas de cada um dos estudantes, ela também nos abre outras portas, outras interpretações.

Do exercício de selecionar imagens e/ou textos poéticos, objetivamos incentivar a reflexão sobre o fazer docente. Propomos escolhas que expusessem um pensamento visual, uma curadoria de imagens do cotidiano, que pudessem destacar a centralidade da imagem e, ao mesmo tempo, pudessem se reconhecer como caminhantes.

\section{O que dizem os estudantes da licenciatura em Música?}

Diferentemente do contexto de atuação dos acadêmicos de Artes Visuais, os alunos do curso de Música não planejaram e nem atuaram nos contextos escolares, e sim, observaram, durante um mês, aulas de Música na Rede Municipal de Educação de Florianópolis. O objetivo da atividade de observação no contexto escolar é compreender a escola enquanto instituição que compõe a atual estrutura sociocultural e política do Brasil, permitindo ao acadêmico uma contextualização e reflexão sobre a situação atual do ensino de Música na escola. Busca-se também, por meio da observação escolar, uma compreensão da relação entre música e currículo escolar e as funções da aula de Música na vida de crianças e adolescentes. Acreditamos que nada influencia mais na formação inicial de um(a) licenciando(a) do que a inserção do futuro professor(a) de Música no contexto escolar. 
As atividades realizadas ficaram concentradas em cinco pontos principais. Era preciso relatar sobre a instituição de ensino, descrevendo a escola, se há salas específicas para o trabalho com artes/música, nas atividades extracurriculares, se há alunos com necessidades especiais incluídos, indicando qual o tipo de necessidade. O segundo ponto a ser descrito era sobre o professor, sua formação, tempo de atuação na escola, por exemplo. O terceiro ponto a ser observado eram as características da turma, ou seja, se a atividade musical observada era curricular ou não, descrever o grupo de alunos, comportamentos, relação com a prática musical. O quarto ponto remete-se ao trabalho de Educação Musical desenvolvido na unidade escolar. Os acadêmicos deveriam relatar sobre as práticas musicais realizadas, identificando as reações das crianças às práticas musicais desenvolvidas, os conteúdos musicais trabalhados, os objetivos das atividades e, finalmente, os recursos utilizados, tais como instrumentos musicais, ferramentas tecnológicas e o ambiente físico em que a atividade era desenvolvida. Os acadêmicos ainda poderiam relacionar outros pontos a comentar com relação ao ensino de Música.

As reflexões dos alunos tiveram duas questões como base. A primeira partiu da reflexão do texto de Roseli C. Fontana (2003): "Como nos tornamos professoras?" O texto discute qual o significado e as múltiplas determinações do processo histórico-social, constituindo-o como prática e função social de um grupo de professoras. Acredita-se que as relações intersubjetivas, mediadas e materializadas na palavra e nos relatos, tal qual apontado pela autora, poderiam ajudar os acadêmicos a resgatar os processos educativos do contexto observado e, também os seus próprios, ainda em construção. Desse modo, a questão colocada para debate foi: Como nos tornamos professores? E, ao mesmo tempo, trazendo essas discussões para o campo da Educação Musical, dimensionamos para uma segunda reflexão: Como se constrói um professor de Música? Para responder essas questões, os acadêmicos deveriam escolher uma fotografia/imagem ou música, podendo estar relacionadas ao contexto da observação escolar ou não, mas que trouxessem em evidência elementos vivenciados durante o ano letivo nas disciplinas de Educação Musical e Escola.

A seguir, apresentamos um quadro com as respostas dos licenciandos e suas respectivas escolhas de imagens ou músicas:

Tornamo-nos professores desde o momento que transmitimos algo ao nosso semelhante, desde o ensino de boas 
Tenho a sensação de que a escola não comporta mais os métodos que estão sendo aplicados hoje. Acho que a figura que escolhi reflete isso, "as peças estão fora do lugar". (Depoimento de Ronaldo)

Há uma grande importância nas observações escolares, pois elas possibilitam uma maior aproximação da realidade escolar. Trabalhar em projetos dentro das escolas públicas, aumentar o contato com estes espaços e, cada vez mais, naturalizar o contexto trazidos por eles.

(...) O professor de Música deve, primeiramente, dominar mais de um instrumento musical. E o seu domínio diante deles deve ser muito bom. Há também de ter contato com Faculdades de Música e ir atrás de técnicas pedagógicas para aperfeiçoar a sua aula. O professor de Música se constrói por sua vontade e disciplina, por ser um músico empenhado a passar a luz do conhecimento para seus futuros alunos. (Depoimento de José)

Acho que nos tornamos professores já quando aprendemos coisas com nossos pais, ainda na infância. Um sábio professor que sabe conduzir, lecionar e encantar desperta nas crianças tal aptidão de querer aprender as coisas e de solucionar problemas (...). Um professor de Música por si só, possui características ímpares, pois é um ser que trabalha com sentimentos, com afetos e com muita Matemática, embora se tratando de Música. Para construirmos seres tão especiais, precisamos quebrar os paradigmas, pois a arte de fazer música também é um árduo e valioso trabalho, (...). Muitas chegam em casa e falam para os pais que vão ser músicos e os pais são os primeiros obstáculos, com argumentos de que isso não é rentável, ou profissão de vagabundo, ou isso não é profissão. Se mesmo com todos esses questionamentos, a criança se mantiver firme na sua vontade, ainda terá que enfrentar a sociedade, os amigos e vizinhos. Por isso eu acho que as políticas públicas têm que rever seus conceitos e valorizar os atuais professores, para que vejam a profissão com os olhos que a Música merece. (Depoimento de Kaká)

Ser professor é caminhar por uma estrada sem fim. Buscar infinitamente por respostas a perguntas que nunca cessam. Cada novo grupo de alunos pode trazer surpresas e tornar necessária uma reformulação de nós mesmos e de nossos métodos. Por isso considero que um professor se forma pelo eterno desejo de responder a essas questões e enfrentar esses desafios. É uma caminhada sem fim em busca do conhecimento
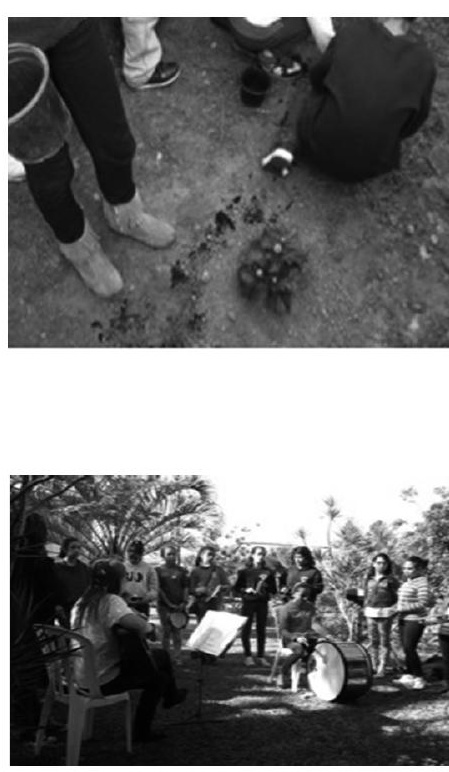

Músico é um ser curioso que gosta de misturar as coisas como um químico, que escreve suas fórmulas como matemático e pensa como filósofo, entende de coração como um cardiologista... Por que não respeitá-lo?

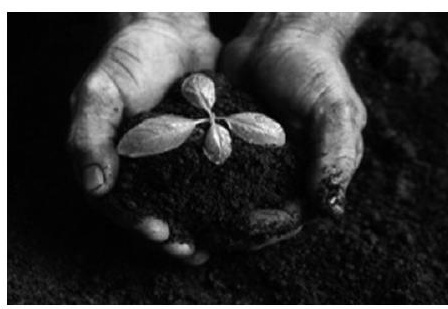


Os depoimentos dos alunos apontam para diferentes abordagens acerca da formação e do papel dos professores de Música na atualidade. Da mesma forma como encontramos falas que destacam a necessidade de autoformação e conhecimento sobre música para ensinar "reformulação de nós mesmos e de nossos métodos" (depoimento de Júlio), noutras falas destaca-se a necessidade da valorização do profissional que está em sala de aula.

Os relatos foram críticos quanto à falta de reconhecimento da profissão. Vários acadêmicos se referem às dificuldades inerentes ao dia a dia do ambiente escolar. No caso da Música, as escolas observadas pertencem ao município de Florianópolis, que vive uma realidade atípica em relação aos demais municípios catarinenses, pois a aula de Música está presente na grade curricular da Rede Municipal de Educação desde 1999. Então, muitas escolas têm assegurada a presença de um professor habilitado na aula de Música. Mas, mesmo tendo esse diferencial importante, as condições de trabalho ainda não são adequadas, de acordo com o ponto de vista de alguns graduandos de Música:

[...] teve uma aula que a professora de Música precisou explicar para os alunos a importância de cuidar do espaço da sala e dos cuidados com o uso dos materiais. Os alunos e a professora passaram a aula inteira varrendo a sala e organizando o espaço que serve para as atividades musicais, porque a sala é utilizada, também, por outras atividades da escola. (Depoimento de Juliana).

Vários acadêmicos atribuem à atividade de ser professor um desejo de mudar as atuais condições de trabalho. "As condições, quando favoráveis para a formação e trabalho deste profissional, com certeza, mudam a perspectiva e o seu desempenho". (Depoimento de Jonas). Fica latente nos depoimentos, nas imagens e nas sonoridades escolhidas, o perfil de esperança e compromisso com a profissão, na perspectiva de fazer o mundo mais humano, como no depoimento de Branca: "unimos um pouco de utopia com muita coragem para enfrentar todos os desafios que estão por vir, com a certeza de que, se o futuro de uma criança for modificado por causa daquela aula, já valeu a pena".

Os acadêmicos que questionam os rumos da educação na contemporaneidade, em que, muitas vezes, a esperança ainda 
impera, apesar do descompasso elucidado pelas letras das músicas escolhidas pelos acadêmicos de Música ou, mesmo, pelas peças de um grande jogo que não encaixam mais, na sua grande maioria, ainda acreditam no poder transformador de realidades que o professor tem.

\section{Análise dos processos na perspectiva de uma formação crítica}

A conquista do processo de amadurecimento, a construção do desejo pela docência, a compreensão do universo educacional, são dimensões bastante singulares para cada aluno, não há um modelo, não há uma receita, o que fazemos é propor um processo reflexivo para que possam estar aptos em suas decisões. Uns se apegam mais a uma determinada faixa etária, outros a um determinado conteúdo do campo das Artes Visuais ou da Música. Mas observa-se nessa relação de docência, que se constrói ao longo do semestre, que aquele primeiro contato, as primeiras falas, cheias de experiências vividas, de pré-conceitos cristalizados, de teorias pouco elaboradas, da indefinição de um mapa conceitual, vão dando lugar a um sujeito posicionado, um sujeito que deseja transformar-se e transformar o processo educativo em algo prazeroso, flexível e, principalmente, significativo. As falas que se construíram na coleta de dados e as imagens mostram essa caminhada.

Fica evidenciado que a atividade docente exercida de forma contínua vai modelando o processo de cada professor, inclusive a partir das decisões político-pedagógicas, do engajamento no contexto artístico, na inserção social na escola e na compreensão da contribuição do ato de educar para a vida daqueles que transitam no universo escolar. Mas o processo reflexivo não emerge somente da ação prática, o exercício docente alienado não se transforma. É justamente a aproximação mediada que estimula a construção de uma formação crítica. Como nos indica Tardif (2008), os saberes dos professores são compostos por vários elementos, um saber plural, formado pela junção da formação profissional, dos saberes disciplinares, curriculares e experienciais.

Quais os saberes que servem de base para o ofício de professor? Noutras palavras, quais são os conhecimentos, o saber-fazer, as competências ${ }^{7}$ e as habilidades que os professores mobilizam diariamente, nas salas de aulas e nas escolas, a fim de realizar concretamente as suas diversas tarefas? Qual é a natureza desses saberes? (TARDIF, 2008, p. 9). 
Os saberes de formação profissional são aqueles transmitidos por instituições formadoras, nas quais os docentes, juntamente com o ensino, constituem objetos de saber para as Ciências Humanas e da Educação. E algumas dessas ciências, ao produzirem conhecimento, passam a incorporá-lo à prática do professor. Os saberes disciplinares são saberes também transmitidos por instituições de formação inicial e continuada de professores e se referem a saberes correspondentes a diversos campos de conhecimento, que estão dentro das universidades, sob a forma de disciplinas que, posteriormente, serão incorporados à prática docente. Os saberes curriculares, por sua vez, apresentam-se sob a forma de programas escolares, em que a unidade escolar categoriza, apresentando os objetivos, conteúdos, métodos que os professores devem aprender a aplicar. Por fim, os saberes experienciais, que são saberes desenvolvidos no exercício de suas funções como professor, baseados não somente nesse seu trabalho cotidiano, mas também no conhecimento de seu meio.

Na perspectiva da formação inicial dos alunos dos cursos de licenciatura em Artes Visuais e Música, os saberes experienciais recebem destaque, justamente por ser este um saber que é produzido pelo contato direto com a realidade, pois esse saber estaria diretamente ligado ao espaço onde o licenciando exercita sua prática diária, na forma de estágio ou mesmo de observação escolar. Neste caso, ao fazer a relação com os conceitos de saber dos professores descritos por Tardif (2008), podemos considerar que o saber em construção também se aplica aos acadêmicos, pois são esses saberes que constituirão, no futuro, o cabedal de conhecimento necessário para a atuação no contexto escolar do ensino de Arte.

Nesse processo mediado, as teorias, os registros e as vivências docentes compartilhadas é que tornam o processo reflexivo contundente. As falas abaixo evidenciam o processo de estar consciente do que é tornar-se professor na contemporaneidade, processo esse que vai se moldando junto com a formação.

O trabalho de observação das aulas e discussão dos mesmos depois, foi muito interessante para percebermos que cada escola é diferente, bem como ver o ponto de vista dos colegas em relação às experiências vividas. (Depoimento de Branca)

A disciplina, em minha opinião, trabalhou muito bem a questão do cotidiano na escola e as implicações de estarmos inseridos em um grande sistema de ensino. Das atividades, mui- 
tas delas me fizeram repensar sobre educação, sobre a minha forma de ensinar na EJA e até que ponto aquela metodologia e nossas ações estão de fato emancipando aquelas pessoas [...]. Nossas falas sobre as dificuldades de ensinar, com experiências de como proceder, nos motiva e ajuda a enxergar o processo de ensino com mais clareza. Achei importantíssimo termos o momento reservado para a visita às escolas, onde pude entender como os professores de Música conseguem fazer mágica e trabalhar a música no ensino formal tão engessado. (Depoimento de Lurdes).

Buscamos ao longo das disciplinas de Estágio I e de Educação Musical e Escola, propor encaminhamentos, pois o professor é o responsável pelo processo de formação de seus alunos, inclusive por construí-lo colaborativo e participativo entre o grupo. Concebemos a reflexão como a abordagem prioritária para o exercício de uma atividade crítica. A reflexão como processo que problematiza, que elenca aspectos da arte, da sua inserção social e das possibilidades de tornar-se parte da escola. Nas palavras de Lipovetsky e Serroy (2014, p. 38), "claramente, a vida na sociedade estética não corresponde às imagens de felicidade e de beleza que difunde em abundância". Com outras palavras, Ronaldo analisa em seu depoimento: "Acho que a figura que escolhi reflete esse descompasso que observei entre o que acontece na sala de aula, 'as peças estão fora do lugar."'

Se por um lado a sociedade faz uma promessa de beleza, de idealização do cotidiano, por outro, nossos estudantes se deparam com contextos não tão adequados, que exigem ações artísticas em consonância com ações políticas. Nesse cenário, trabalha-se para não tornar culpado o professor e, concomitantemente, para criar um espaço de resistência, de novas visualidades, de reflexão e de ação, numa perspectiva das Artes e, como aborda Eagleton (2011), da compreensão da cultura como um fenômeno contextualizado. No relato de Júlio, podemos observar essa dimensão da singularidade:

Cada novo grupo de alunos pode trazer surpresas e tornar necessária uma reformulação de nós mesmos e de nossos métodos. Por isso considero que um professor se forma através do eterno desejo de responder essas questões e enfrentar esses desafios. [...] um professor precisa de experiência, através de estágios e bolsas, é onde ele começa a pôr em prática o que aprendeu e está aprendendo. Como em qualquer profissão, o 
professor precisa da prática e da teoria para se construir como um bom profissional. (Depoimento de Júlio).

O fato dos acadêmicos compreenderem que tornar-se professor exige "abertura para aprender" e que não basta ser apenas um "bom artista ou bom músico" no contexto atual, ressalta a necessidade de se aprender os processos de ensinar, aliados a uma leitura política da realidade sociocultural.

\section{Considerações finais}

Cabe destacar que os estudantes das licenciaturas iniciam seus cursos bastante jovens, pouca experiência de vida e muito menos de escola, de docência. De fato, a única experiência que a maioria vivencia antes do início do estágio é a de estudante. Aqueles que atuam em projetos institucionais também apresentam diferenças de formação e, portanto, de prática pedagógica no estágio. Por outro lado, também é possível perceber diferentes formas de lidar com o cotidiano da universidade. Os cadernos deram lugar aos tabletes, os textos impressos à leitura no celular, fatos que também influenciam a visualidade presente nas salas de aulas. A postura de aluno é mais participativa, emite mais opiniões, embora com menos embasamento teórico para isso. É possível perceber entre os estudantes de Artes Visuais uma forte influência dos escritos pós-modernos, um apelo ao ecletismo teórico e uma falta de leitura dos clássicos. As atividades desenvolvidas no plano pedagógico da disciplina buscaram enfatizar a reflexão sobre a formação, sobre o compromisso com a docência, sua poética e seus desdobramentos na ação prática na escola.

Finalmente, cabe aos cursos de licenciatura melhor articular as categorias propostas a fim de que elas possam fazer parte do ideário dos professores formadores, criando laços entre as disciplinas teóricas e práticas, artísticas e de formação pedagógica, de modo que o estudante em formação não perceba dualidades, conflitos de interesses, embora existam entre elas diferenças de processo.

As cinco dimensões - contextual, simbólica, pedagógica, artística e trabalho, elaboradas para nortear as práticas de ensino das disciplinas de Estágio I e Educação Musical e Escola, foram avaliadas a partir da produção dos textos dos acadêmicos de como se constrói um professor de Artes e, também, a partir das imagens e sonoridades escolhidas para representar, simbolicamente, este processo. 
Na dimensão contextual os acadêmicos das duas licenciaturas puderam compreender o contexto onde a escola está inserida e o papel das artes nesse cenário, bem como os limites de uma ação transformadora diante dos desafiantes ditames da política educacional. Na dimensão simbólica, ficou em evidência a subjetividade, o desejo, a humanidade presentes no ato de educar e de apropriar-se da Arte socialmente, compreendendo a criação de novas visualidades e novas sonoridades como formas de resistência. Imagens como aquelas que trazem a figura do professor nas suas atividades em sala de aula, das atividades de exploração, seja do uso do pincel ou mesmo da criança que toca um instrumento musical, trazem o poético, o lírico na prática da docência.

A pedagogia do ensino de Arte, presente na categoria pedagógica, pretende abordar o como ensinar, na perspectiva dos eixos apresentados. Neste sentido, desenhar uma pedagogia para o Ensino de Arte nas licenciaturas amplia as condições de trabalho do professor, numa perspectiva de conhecer e vivenciar os processos pedagógicos. Os depoimentos ilustram que este processo está latente na perspectiva dos acadêmicos.

$\mathrm{Na}$ categoria artística, os estudantes puderam observar como o Ensino de Arte acontece nas escolas, reconhecer ou não essas práticas na sua própria formação artística, confirmando a importância das disciplinas de conteúdos artísticos ao longo da graduação, e da necessária conversa entre as áreas, com o objetivo de diminuir a dualidade. Os estudantes que atuaram na proposição de aulas puderam relacionar os conhecimentos pedagógicos e artísticos, ressaltando o papel da Arte e seus processos, desde o fazer até o distribuir, a organização e seleção dos conteúdos formativos, executando sua própria curadoria pedagógica. Como já apontado, a perspectiva de formação de repertório, amplia as vivências estéticas na vida do professor e de seus alunos, bem como a fruição de objetos artísticos, da reflexão sobre o papel da indústria cultural na formação de consumidores midiáticos, das tecnologias e sua participação no cotidiano, ajudando a compreender e a modificar as concepções de Arte, presentes nas camadas populares. Esse é o papel da Arte na escola, disseminar novas perspectivas para além daquelas massificadas pela mídia.

A formação política necessária para reconhecer as condições de trabalho, ao mesmo tempo lutar por sua qualificação, exige o debate acerca do sistema político-econômico e educacional, investigando as políticas públicas e seus interesses na definição de modelos docentes. Por isso, na dimensão sis- 
tema educacional, destacamos a importância da participação do Estado como mantenedor da educação pública, e muitas vezes, da manutenção das desigualdades.

Na dimensão condições de trabalho, a percepção dos processos socioculturais amplia a compreensão do sistema educativo e permite que o professor não seja responsabilizado pelos déficits educacionais. Fica claro na visão dos estudantes o estereótipo do papel de herói, de guerreiro, de guia e mediador do conhecimento para dar conta de todas as demandas a ele atribuídas. Quanto mais cedo nossos licenciados de Artes compreenderem o seu papel na trajetória educacional, mais eficazmente poderão se preparar para atuarem na construção da profissão 'professor'.

\section{NOTAS}

1. Segundo Barbosa (2008) e por recomendação de Lúcia Pimentel, essa éa forma de grifar o movimento Arte/Educação usando a barra ao invés do hífen como forma de significar com base na linguagem informacional, "pertencer a".

2. Dados do plano de ensino da disciplina na licenciatura em Artes Visuais.

3. Dados do plano de ensino da disciplina na licenciatura em Música.

4. Limitados ao desenvolvimento do artigo e sua problemática não faremos nessa oportunidade os desdobramentos dos eixos de Saviani para o Ensino de Arte.

5. Utilizamos nomes fictícios para manter em sigilo a identidade dos discentes.

6. Ressalvamos aqui os cursos de licenciatura que já possuem disciplinas específicas voltadas para o Ensino de Arte na Educação Infantil.

7. Ressalvamos o uso da palavra competência que recebe uma crítica contundente, pois poderia estar vinculada a uma culpabilização do professor (competente/incompetente), ou mesmo a um neo-tecnicismo.

\section{Referências}

BARBOSA, Ana Mae. Arte/Educação contemporânea: consonâncias internacionais. São Paulo: Cortez, 2008.

BRASIL. Lei n. 11.769, de 18 de agosto de 2008. Altera a Lei n. 9394/96, para dispor

sobre a obrigatoriedade do ensino de música na educação básica. Brasília: Presidência da República, 2008.

EAGLETON, T. A ideia de cultura. São Paulo: UNESP, 2011.

FONTANA, R.A.C. Como nos tornamos professoras? 2. ed. Belo Horizonte: Autêntica, 2003.

GASPARIN, J. L. Uma Didática para a Pedagogia Histórico-Crítica. 3. ed. Campinas, SP: Autores Associados, 2002. 
LIPOVETSKY, G. e SERROY, J. O capitalismo estético na era da globalização. Portugal: Edições 70, 2014.

NOGUEIRA, M. A. Arte e experiência estética: o assombro aproximando crianças e adultos. In: ZANELLA, S.R. da S. (Org.). Arte, Estética e Formação Humana: possiblidades e críticas. Campinas, S.P.: Alínea, 2013. p. 119-126.

PERES, J.J.J. Arte, psicología y educación: fundamentos vygotskyana de la educacion artística. Madrid: Machado Libros, 2002.

RAMIREZ, F.G.T. Daño cerebral óptimo: arte, diseño y tecnología. In: CANIZAL, E.P. (Org.). La inquietante ambigüedad de la imagen. México: Azcapotzalco, 2004. p. 87-122.

SAVIANI, D. Escola e Democracia, São Paulo: Cortez Autores Associados, 2009.

. Educação: Do Senso Comum à Consciência Filosófica. 13. ed. Campinas, SP: Autores Associados, 2000.

TARDIF, Maurice. Saberes docentes e formação profissional. 9. ed. Petrópolis, RJ: Vozes, 2008.

VIGOTSKY, L. S. Teorias de las emociones. Madrid: Ediciones Akal, 2004.

Recebido em: 27/02/15

Aceito em: 08/04/15 


\section{MARIA CRISTINA DA ROSA FONSECA DA SILVA cristinaudesc@gmail.com}

Licenciada em Educação Artística pela Universidade do Estado de Santa Catarina (UDESC). Mestre em Educação pela Universidade Federal de Santa Catarina (UFSC) e doutora em Engenharia de Produção pela mesma instituição. Atua como professora do Mestrado e Doutorado em Artes Visuais da UDESC, desenvolvendo pesquisas na área de formação de professores de Artes Visuais. Atualmente coordena o projeto bilateral Observatório da Formação de Professores de Artes Visuais.

\section{REGINA FINCK SCHAMBECK \\ regina.finck@gmail.com}

Licenciada em Educação Artística-Habilitação em Música pela Universidade do Estado de Santa Catarina (UDESC), com mestrado e doutorado pelo Programa de Pós-Graduação em Educação da Universidade Federal do Rio Grande do Sul (UFRGS). Atua no Departamento de Música e no Programa de Pós-Graduação em Música - PPGMUS, desenvolvendo pesquisas na área de formação de professores, inclusão de alunos com deficiências e a repercussão das políticas públicas de educação especial. 